This item was submitted to Loughborough's Research Repository by the author.

Items in Figshare are protected by copyright, with all rights reserved, unless otherwise indicated.

\title{
Electrocatalytic oxidation of ethanol and ethylene glycol on cubic, octahedral and rhombic dodecahedral palladium nanocrystals
}

\section{PLEASE CITE THE PUBLISHED VERSION}

https://doi.org/10.1039/C7CC08793D

\section{PUBLISHER}

(c) Royal Society of Chemistry

\section{VERSION}

AM (Accepted Manuscript)

\section{PUBLISHER STATEMENT}

This work is made available according to the conditions of the Creative Commons Attribution-NonCommercial 4.0 International (CC BY-NC 4.0) licence. Full details of this licence are available at: https://creativecommons.org/licenses/by-nc-nd/4.0/

\section{LICENCE}

CC BY-NC-ND 4.0

\section{REPOSITORY RECORD}

Ma, Xian-Yin, Ya-Feng Chen, Han Wang, Qiao-Xia Li, Wen-Feng Lin, and Wen-Bin Cai. 2018.

"Electrocatalytic Oxidation of Ethanol and Ethylene Glycol on Cubic, Octahedral and Rhombic Dodecahedral Palladium Nanocrystals". figshare. https://hdl.handle.net/2134/32094. 


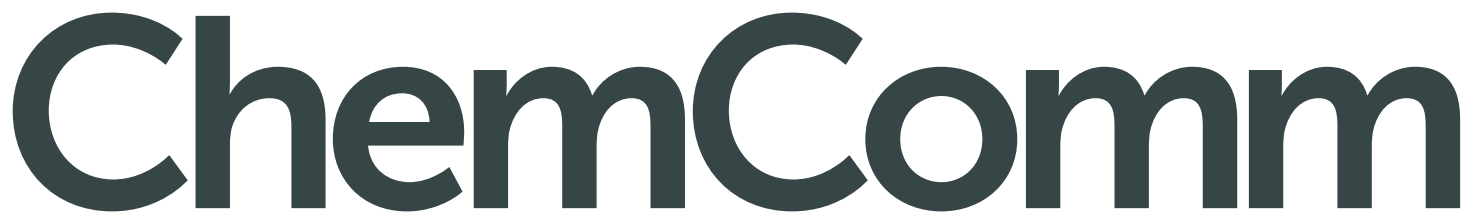

\section{Accepted Manuscript}

This article can be cited before page numbers have been issued, to do this please use: $\mathrm{X}$. Ma, Y. Chen, H. Wang, Q. Li, W. Lin and W. Cai, Chem. Commun., 2018, DOI: 10.1039/C7CC08793D.
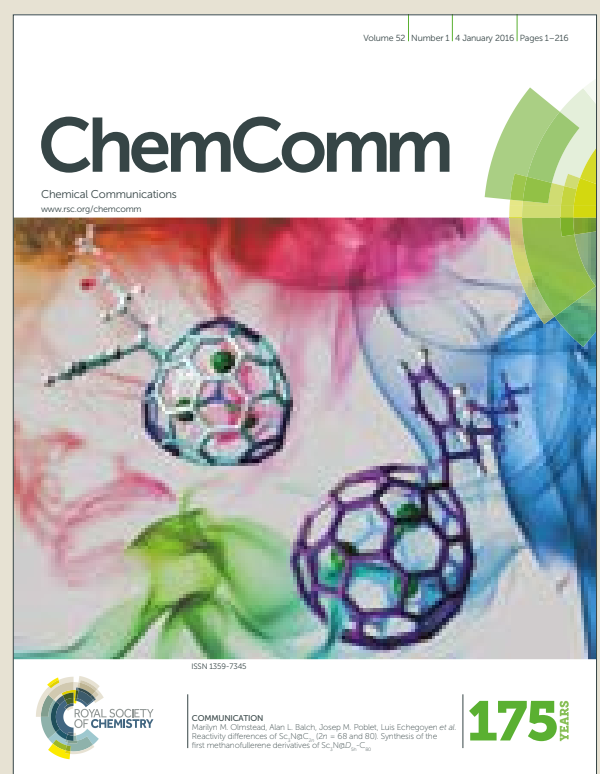

This is an Accepted Manuscript, which has been through the Royal Society of Chemistry peer review process and has been accepted for publication.

Accepted Manuscripts are published online shortly after acceptance, before technical editing, formatting and proof reading. Using this free service, authors can make their results available to the community, in citable form, before we publish the edited article. We will replace this Accepted Manuscript with the edited and formatted Advance Article as soon as it is available.

You can find more information about Accepted Manuscripts in the author guidelines.

Please note that technical editing may introduce minor changes to the text and/or graphics, which may alter content. The journal's standard Terms \& Conditions and the ethical guidelines, outlined in our author and reviewer resource centre, still apply. In no event shall the Royal Society of Chemistry be held responsible for any errors or omissions in this Accepted Manuscript or any consequences arising from the use of any information it contains. 


\section{Electrocatalytic Oxidation of Ethanol and Ethylene Glycol on Cubic, Octahedral and Rhombic Dodecahedral Palladium Nanocrystals}

Received 00th January 20xx, Accepted 00th January 20xx

DOI: $10.1039 / \times 0 \times x 00000 x$

\author{
Xian-Yin Ma ${ }^{a, c}$, Yafeng Chen ${ }^{b}$, Han Wang ${ }^{c}$, Qiao-Xia Lia , Wen-Feng Lin ${ }^{* b}$, Wen-Bin Cai ${ }^{*}{ }^{*}, a$
}

www.rsc.org/

Cubic, octahedral and rhombic dodecahedral Pd nanocrystals were synthesized and examined as nanocatalysts for electro-oxidation of ethanol and ethylene glycol. Combined electrochemical measurements and density functional theory calculations reveal that nanofacet-dependent affinity and reactivity of $\mathrm{OH}_{\text {ads }}$ and $\mathrm{CO}_{\text {ads }}$ are closely linked to the $\mathrm{C} 2$ alcohol oxidation activities, with the highest reactivity found on the Pd nanocubes bounded by $\{100\}$ facets.

Ethanol and ethylene glycol based direct alcohol fuel cells are particularly attractive for portable power applications, owing to their theoretically high energy densities, low toxicity and facile generation of the fuels from biomass. ${ }^{1,2}$ Alternatively, alcohol electro-reforming is an energy-efficient, low cost and environmentally friendly technology to produce clean hydrogen at the cathode and valuable chemicals from biomass-derived alcohol oxidation at the anode, in a simple electrolysis cell at low temperature and atmospheric pressure. ${ }^{3}$ For both of the fuel cell and hydrogen technologies, the efficient oxidation of the $\mathrm{C} 2$ alcohol by means of electrocatalysis is essential, and the efficiency is largely determined by the catalysts employed.

Due to the rarity and high cost of Pt, Pd-based catalysts have been investigated as alternative promising catalytic materials for C2 alcohol oxidation in alkaline media given that they compete with traditional Pt-based ones in term of electrocatalytic activities at high $\mathrm{pH}^{4-7}$ Although significant technical progress has been achieved on anion exchange membranes for the direct alkaline alcohol fuel cells and the alcohol reforming electrolytic cells, oxidation of $\mathrm{C} 2$ alcohols on $\mathrm{Pd}$ surfaces has received far less attention than that on $\mathrm{Pt}$

\footnotetext{
a. Shanghai Key Laboratory of Materials Protection and Advanced Materials in Electric Power, College of Environmental and Chemical Engineering, Shanghai University of Electric Power, Shanghai 200090, China.

b. Department of Chemical Engineering, Loughborough University, Loughborough, Leicestershire, LE11 3TU, U.K. Email: w.lin@lboro.ac.uk

c. Shanghai Key Laboratory of Molecular Catalysis and Innovative Materials, Collaborative Innovation Center of Chemistry for Energy Materials, Department of Chemistry, Fudan University, Shanghai 200433, China.

Electronic Supplementary Information (ESI) available. See DOI: 10.1039/c000000x/
}

surfaces, ${ }^{8,9}$ hindering the development of more efficient $\mathrm{Pd}$ based catalysts.

Facet control is one of the effective tactics to attain surface structure manipulation that may lead to the design of high performance catalysts. ${ }^{10-12}$ Studies on Pd bulk single crystals have shown that the crystallographic orientations can have significant impacts on the electrocatalysis of formic acid oxidation and oxygen reduction. ${ }^{13-15}$ The three basal planes (111), (100) and (110), are of fundamental interest since they may be combined to constitute structurally higher index planes of single crystals. ${ }^{16}$ It has been reported that the formic acid oxidation activity on $\mathrm{Pd}$ single crystals increases in the order of $\operatorname{Pd}(111)<\operatorname{Pd}(110)<\operatorname{Pd}(100)$ in sulfuric acid solution, ${ }^{13}$ while the oxygen reduction activity follows the order of $\mathrm{Pd}(110)<\mathrm{Pd}(111)$ $<\operatorname{Pd}(100)$ in perchloric acid solution. ${ }^{14}$

From the practical viewpoint, $\mathrm{Pd}$ nanocrystals are much more preferred to be employed as the catalysts compared to Pd bulk crystals. ${ }^{17}$ The preferential nanofacets could be created by tailoring the shapes of nanocrystals, e.g., Pd cubes, octahedrons (Octs) and rhombic dodecahedrons (RDs) are enclosed predominantly by $\{100\},\{111\}$ and $\{110\}$ nanofacets, respectively. ${ }^{16}$ Clearly, a systematic investigation into the electrocatalytic activities of these model Pd nanocatalysts for ethanol and ethylene glycol oxidation in alkaline media is highly demanded and timely for the development of direct alcohol alkaline fuel cells and electro-reforming cells.

Pd cubes, RDs and Octs nanocrystals were obtained via wet chemistry one-pot synthesis ${ }^{18,19}$ and then casted on a glassy
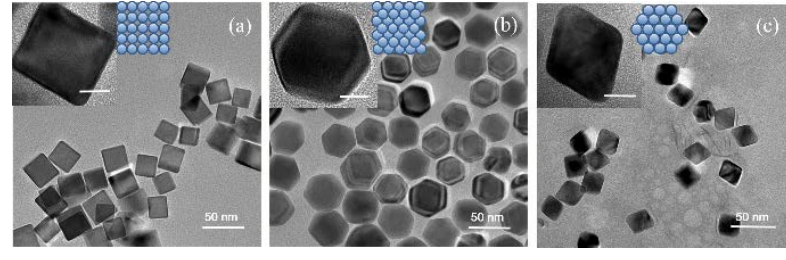

Figure 1. Transmission electron microscopic (TEM) images of Pd cubes (a), RDs (b) and Octs (c). The inserts are the zoomed-in images for single particles at the scale bar of $10 \mathrm{~nm}$, and the corresponding schematic surface atomic arrangements. 
carbon electrode for the electrocatalytic evaluation (see $\mathrm{ESI}+$ for details).

The transmission electron microscopic (TEM) images of the as-synthesized Pd cubes (a), RDs (b) and Octs (c) with welldefined shape and a high yield/selectivity (>90\%) are shown in Figure 1 and Figure S1. The mean sizes in the edge-length lie around $25.3 \pm 2.1,23.6 \pm 2.7$ and $21.5 \pm 1.9 \mathrm{~nm}$ for Pd cubes, RDs and Octs, respectively. More details of nanofacet characterization and the XRD data are shown in Figures S2 and S3, which all support the identified surface structures. As demonstrated in the previous report, ${ }^{20} \mathrm{Pd}$ nanocrystals of these similar sizes should not have a significant size effect on their specific activities, however the electrochemical properties of $\mathrm{Pd}$ nanocrystals are highly dependent on their surface cleanness, and the removal of residual surfactants on the nanocrystals after the wet chemistry synthesis is thus essential for a reliable comparison. Based on our previous reports, ${ }^{6,19}$ the removal of CTAB/CTAC residues on Pd nanocrystals supported on glassy carbon electrode was enabled by effectively utilizing the COadsorption displacement tactics in a CO-bubbled $0.5 \mathrm{M} \mathrm{H}_{2} \mathrm{SO}_{4}$ solution at $0.35 \mathrm{~V}$ vs RHE for $900 \mathrm{~s}$ followed by subsequent anodic $\mathrm{CO}_{\text {ads }}$ stripping. Figure $\mathrm{S} 4$ shows the cleaning treatment effect, which confirms the clean surface was obtained.

Figures $2 \mathrm{a}$ and $2 \mathrm{~b}$ show the cyclic voltammograms (CVs) recorded for surface cleaned $\mathrm{Pd}$ nanocrystals in $0.5 \mathrm{M} \mathrm{H}_{2} \mathrm{SO}_{4}$ and $1.0 \mathrm{M} \mathrm{NaOH}$ electrolytes, respectively. In acidic media, the formation/reduction of surface $\mathrm{PdO}$ and hydrogen/bisulfate adsorption/desorption current peaks on differently faceted $\mathrm{Pd}$ nanocrytals were observed over distinct potential regions, similar to the voltammetric features for the corresponding Pd bulk single crystal electrodes. ${ }^{21}$

Shape-dependent unique voltammetric features for the formation/reduction of $\mathrm{PdO}$ and hydrogen adsorption /desorption processes were also observed in alkaline media
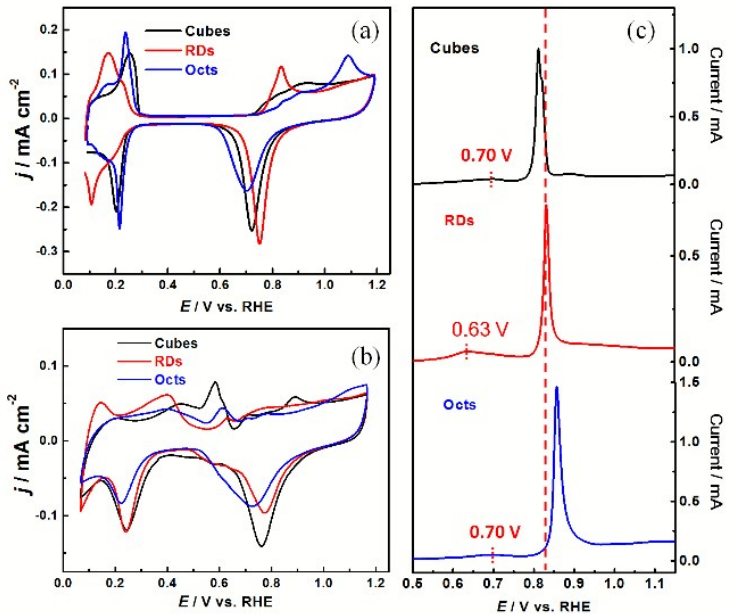

Figure 2. Cyclic voltammograms (CVs) of Pd nanocrystals recorded in $0.5 \mathrm{M}$ $\mathrm{H}_{2} \mathrm{SO}_{4}$ (a) and $1.0 \mathrm{M} \mathrm{NaOH}$ (b) electrolytes, respectively. The $\mathrm{CO}$ stripping curves obtained from the three types of Pd nanocrystals in $1.0 \mathrm{M} \mathrm{NaOH}$ are also shown here (c). Scan rate: $50 \mathrm{mV} \mathrm{s}^{-1}$. The current densities in (a) and (b) are shown by normalizing the measured currents to the electroactive areas of designated Pd nanocrystals (see text, vide infra). over the high and low potential regions, ${ }^{22}$ respectively, see

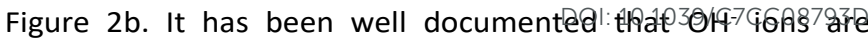
chemisorbed over a broad potential region before and during the initial stage of the surface oxide layer formation. ${ }^{22,}{ }^{23}$ At potentials below ca. $0.70 \mathrm{~V}$, the redox current peaks appearing in the voltammograms are related to the hydrogen desorption/adsorption and $\mathrm{OH}$ adsorption /desorption processes. ${ }^{9,24}$ To get an insight into the $\mathrm{OH}$ formation potentials on the different Pd facets, we performed DFT calculations (see ESIt for details of DFT computational method) and the main results are presented in Figure 3, with the supporting adsorption energy data given in the Table S1.

From the DFT simulation on a simplified surface model as explained in the $\mathrm{ESI}$, the onset potential of $\mathrm{OH}$ formation on the three basal Pd planes of (111), (100) and (110) are $0.31 \mathrm{~V}, 0.07$ $\mathrm{V}$ and $-0.13 \mathrm{~V}$, respectively, indicating that the $\mathrm{OH}$ adsorption reaction process on $\mathrm{Pd}(110)$ surface was firstly initiated for its lowest onset potential, although the calculated values are obviously lower than the experimental ones due to the simplified model. It has been well documented that the adsorption of hydroxyl species was most favoured on $\mathrm{Pt}(110)$ followed by $\mathrm{Pt}(100)$ and $\operatorname{Pt}(111) \cdot{ }^{9}$ Meanwhile, an indirect experimental evidence comes from the report that $\mathrm{O}$ species adsorbed at lowest temperature on $\mathrm{Pd}(110)$ followed by $\mathrm{Pd}(100)$ and $\mathrm{Pd}(111)$ at the solid-gas interface, as detected by XPS. ${ }^{25}$ Along this line, the broad peak located at ca. $0.40 \mathrm{~V}$ for $\mathrm{Pd}$ RDs may be attributed to desorption of hydrogen and adsorption of $\mathrm{OH}^{-}$to form $\mathrm{OH}_{\text {ads }}$ on $\{110\}$ nanofacets. The peaks located at ca. 0.585 and $0.615 \mathrm{~V}$, which are too high for the potential of hydrogen desorption, may be assigned to the chemisorption of $\mathrm{OH}^{-}$on $\{100\}$ nanofacets of $\mathrm{Pd}$ cubes and $\{111\}$ nanofacets of Pd Octs 2 respectively. ${ }^{15}, 26$ Since $\mathrm{OH}_{\text {ads }}$ is the essential reactant pair involved in oxidizing the carbonaceous intermediate species including $\mathrm{CH}_{3} \mathrm{C}^{*}=\mathrm{O}, \mathrm{CO}$ and $\mathrm{CH}_{\mathrm{x}}$ during $\mathrm{EOR},{ }^{23,}, 27$ and $\mathrm{HO}-\mathrm{CH}_{2} \mathrm{C}^{*}=\mathrm{O}, \mathrm{CO}$ and $\mathrm{CH}_{x} \mathrm{O}$ during $\mathrm{EGOR}, 6$ the $\mathrm{Pd}$
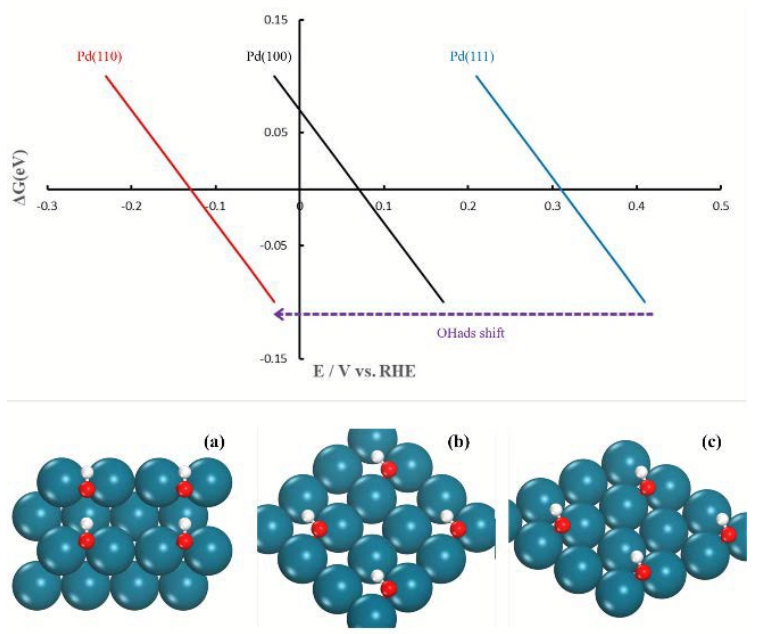

Figure 3. Calculated phase diagram of $\mathrm{OH}$ adsorption on $\mathrm{Pd}(110), \mathrm{Pd}(100)$ and $\mathrm{Pd}(111)$ facets. The optimized configurations of $\mathrm{OH}_{\text {ads }}$ on the bridge sites of the three surfaces are shown in (a) $\mathrm{OH}_{\text {ads }} / \mathrm{Pd}(110)$, (b) $\mathrm{OH}_{\mathrm{ads}} / \mathrm{Pd}(100)$ and (c) $\mathrm{OH}_{\mathrm{ads}} / \mathrm{Pd}(100)$, where red is the $\mathrm{O}$, white is $\mathrm{H}$ and blue is $\mathrm{Pd}$ atoms. 
surface with a relatively facile $\mathrm{OH}_{\text {ads }}$ formation at a lower potential in general favours CO oxidation, EOR and EGOR. It is worth noting that, $\mathrm{OH}_{\text {ads }}$ forms with its coverage increasing over a rather wide potential window, ${ }^{23}$ its formation is essential but not sufficient for initializing the above oxidation processes. The surface reactivity is also dependent on the activation of $\mathrm{C} 2$ reactants and carbonaceous intermediates on different $\mathrm{Pd}$ nanofacets. ${ }^{28}$ Therefore, the resulting electrocatalytic activity of $\mathrm{Pd}$ nanocrystals may vary to some extent case by case for different oxidation reactions.

$\mathrm{CO}$ adsorbate $\left(\mathrm{CO}_{\text {ads }}\right)$ is an intermediate species formed from the $\mathrm{C}-\mathrm{C}$ bond breaking during EOR and EGOR, 6, 27, 29 playing a dual role: one is the reactive species to be further converted to $\mathrm{CO}_{2}$ via $\mathrm{CO}_{\mathrm{ads}}+\mathrm{OH}_{\mathrm{ads}}=>\mathrm{CO}_{2}+\mathrm{H}^{+}+\mathrm{e}^{-}$( further to carbonate in a high $\mathrm{pH}$ alkaline solution), and the other is the poisonous species to block surface active sites for other parallel reactions. ${ }^{27,30}$ For the pre-dosed $\mathrm{CO}_{\text {ads }}$ monolayer on $\mathrm{Pd}$ nanocrystals, the anodic oxidation stripping voltammograms in $\mathrm{N}_{2}$-deaerated $1.0 \mathrm{M} \mathrm{NaOH}$ solution (Figure $2 \mathrm{c}$ ) revealed that the $\mathrm{CO}_{\text {ads }}$ oxidation on $\mathrm{Pd}$ nanocrystals occurs in two distinct potential regions, as demonstrated by the oxidation pre-peak and the main oxidation peak. The pre-peak may arise from the reaction of weakly adsorbed CO (for example, part of linear adsorbed $\mathrm{CO}$, or $\mathrm{CO}_{\mathrm{L}}$ ) with $\mathrm{OH}_{\text {ads }}$ formed at lower potentials. In fact, $\mathrm{CO}$ adsorption on $\mathrm{Pd}$ surfaces may take linear $\left(\mathrm{CO}_{\mathrm{L}}\right)$, bridge $\left(\mathrm{CO}_{\mathrm{B}}\right)$ and hollow $\left(\mathrm{CO}_{\mathrm{H}}\right)$ sites, with increasing $\mathrm{CO}$ adsorption strength. The preference of which depends greatly on $\mathrm{Pd}$ crystalline orientation. An IR spectroscopy study ${ }^{31}$ suggests that despite the highest $\mathrm{CO}_{\mathrm{B}}$ band observed on $\mathrm{Pd}(100),(111)$ and (110), relatively higher portion of $\mathrm{CO}_{\mathrm{L}}$ is present on $\mathrm{Pd}(110), \mathrm{CO}_{\mathrm{B}}$ on $\mathrm{Pd}(100)$, and $\mathrm{CO}_{\mathrm{H}}$ on $\mathrm{Pd}(111)$, respectively. Therefore, the main oxidation current peak could be attributed to the reaction of the majority of $\mathrm{CO}_{\text {ads }}$ with sufficiently high coverage and active $\mathrm{OH}_{\text {ads }}$ on Pd surfaces. ${ }^{32-34}$

The $\mathrm{CO}$ oxidation pre-peak appears at ca. 0.63, 0.70 and $0.70 \mathrm{~V}$ for Pd RDs, cubes and Octs, respectively, being consistent with the adsorption strengths of $\mathrm{OH}_{\mathrm{ads}}$ and $\mathrm{CO}_{\text {ads }}$ on the three basal planes. Nevertheless, the main oxidation peak on $\mathrm{Pd}$ cubes materializes at $0.810 \mathrm{~V}$, was earlier than that on both $\mathrm{Pd}$ RDs $(0.832 \mathrm{~V})$ and Pd Octs $(0.857 \mathrm{~V})$. The slightly delayed oxidation of the majority of $\mathrm{CO}_{\text {ads }}$ on Pd RDs may be caused by the reduced mobility of $\mathrm{CO}_{\mathrm{ads}}$, as well as that of $\mathrm{OH}_{\mathrm{ads}}$, on the stepped $\{110\}$ surface, as compared to that on flat $\{111\}$ and $\{100\} .30$

On the other hand, the total charge associated with $\mathrm{CO}_{\mathrm{ads}}$ stripping may be used to evaluate the exposed electroactive surface areas, that is, 1.08, 2.13 and $0.96 \mathrm{~cm}^{2}$ for Pd cubes, Octs and RDs, casted on glassy carbon electrode, respectively. Therefore, for a reasonable comparison, all the electrochemical current densities presented in this work except those in Figure $2 c$ were respectively normalized to the electroactive areas of the designated $\mathrm{Pd}$ nanocrystals to represent their inherent specific activities.

As compared to the $\mathrm{CO}_{a d s}$ oxidation, the EOR on $\mathrm{Pd}$ electrodes in alkaline media is more complicated, proceeding through the so-called $\mathrm{C} 1$ and $\mathrm{C} 2$ pathways, ${ }^{27,} 29$ in which the minor $\mathrm{C} 1$ pathway involves the $\mathrm{C}-\mathrm{C}$ bond breaking to form $\mathrm{CO}_{\text {ads }}$ and $\mathrm{CH}_{\mathrm{x}}$ surface species at lower potentials, followed by their further oxidation to $\mathrm{CO}_{2}\left(\mathrm{CO}_{3}{ }^{2-}\right)$ at highero.polentafs.87phe majority of $\mathrm{CO}_{\text {ads }}$ species would not start to be further oxidized until the potential is raised higher than $c a .0 .77 \mathrm{~V}$, as can be seen from Figure 2c. Meanwhile, the predominant $\mathrm{C} 2$ pathway may proceed via $\mathrm{CH}_{3} \mathrm{C}^{*}=\mathrm{O}+\mathrm{OH}_{\text {ads }}+\mathrm{OH}^{-}=>\mathrm{CH}_{3} \mathrm{COO}^{-}+\mathrm{H}_{2} \mathrm{O}$ to form acetate, ${ }^{27}$ the acetate may adsorb at the surface to become additional poisoning species at a sufficiently higher potential. ${ }^{9}$

Figure 4(a) shows CVs for Pd nanocrystals in $1 \mathrm{M} \mathrm{NaOH}+1$ $M$ ethanol solution, in which $\mathrm{Pd}$ cubes exhibit the highest peak current density, followed by Pd Octs and Pd RDs. The highest oxidation peak current density on Pd cubes seems consistent with both the lowest barrier for dehydrogenation of ethanol on $\mathrm{Pd}(100)$ indicated by the DFT calculation ${ }^{35}$, and the favourable subsequent oxidation of the majority of $\mathrm{CH}_{3} \mathrm{C}^{*}=\mathrm{O}$ and $\mathrm{CO}_{\text {ads }}$ intermediates on $\mathrm{Pd}$ cubes, inferred from the previous mechanism study $\mathrm{y}^{4,27}$ and the above $\mathrm{CO}$ stripping measurement. In terms of nanofacet dependence, the oxidation onset potential and peak potential for EOR are the lowest on Pd RDs, as compared to those on Pd cubes and Pd Octs, due to the lowest potential for $\mathrm{OH}^{-}$chemisorption on $\{110\}$ nanofacets. Further chrono-amperometric measurement in the same electrolyte indicated the highest EOR oxidation current density maintained on Pd cubes after anodic polarization at $0.67 \mathrm{~V}$ for $3600 \mathrm{~s}$. In fact, $41 \%, 18 \%$ and $13 \%$ of the initial current densities were sustained on Pd cubes, RDs and Octs, respectively (see Figure $4 \mathrm{~b}$ ). The most durable EOR activity on Pd cubes at $0.67 \mathrm{~V}$, as demonstrated in Figure $4 \mathrm{~b}$, may arise from the least accumulation of both $\mathrm{CO}_{\text {ads }}$ and adsorbed acetate species. Otherwise, increasing $\mathrm{CO}_{\text {ads }}$ and acetate coverage may block surface active sites during EOR, resulting in the quicker decay of current densities.

EGOR on Pd electrode in alkaline media seems even more complicated than that for EOR, with the main products being glycolate and glyoxal in the $\mathrm{C} 2$ pathway and the minor product being $\mathrm{CO}_{2}$ or its derivatives in the $\mathrm{C} 1$ pathway besides the surface intermediates $\mathrm{HO}-\mathrm{CH}_{2} \mathrm{C}^{*}=\mathrm{O}, \mathrm{CO}_{\text {ads }}$ and $\mathrm{CH}_{\mathrm{x}} \mathrm{O}_{\text {ads. }}{ }^{6}$
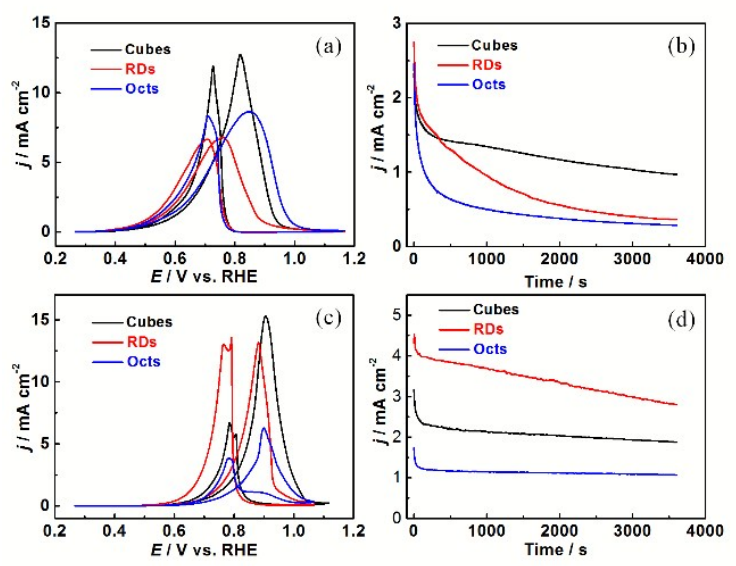

Figure 4. Cyclic voltammograms (CVs) (a) and chronoamperometric curves at $0.67 \mathrm{~V}$ (b) recorded for Pd nanocrystals in $1.0 \mathrm{M} \mathrm{NaOH}+1.0 \mathrm{M}$ ethanol; CVs (c) and chronoamperometric curves at $0.82 \mathrm{~V}$ (d) recorded for $\mathrm{Pd}$ nanocrystals in $1.0 \mathrm{M} \mathrm{NaOH}+1.0 \mathrm{M}$ ethylene glycol. Scan rate for all the CVs: $50 \mathrm{mVs}^{-1}$. The current densities are shown by normalizing the measured currents to the electroactive areas of designated Pd nanocrystals. 
In analogy to the role of $\mathrm{CH}_{3} \mathrm{C}^{*}=\mathrm{O}$ in $\mathrm{EOR}$ at $\mathrm{Pd}^{27}$ our previous spectroelectrochemical study indicates that $\mathrm{HO}-\mathrm{CH}_{2} \mathrm{C}^{*}=\mathrm{O}$ acts as the pivotal intermediate for the $\mathrm{C} 2$ and $\mathrm{C} 1$ pathways in EGOR on Pd in alkaline media. ${ }^{6}$ Figure $4 \mathrm{c}$ shows the corresponding CVs for Pd nanocrystals in $1 \mathrm{M} \mathrm{NaOH}+1 \mathrm{M}$ ethylene glycol solution. The oxidation peak current densities followed the order of $\mathrm{Pd}$ cubes > RDs > Octs, with the onset oxidation potentials shifting positively by nearly $0.20 \mathrm{~V}$, compared to the counterparts in the case of EOR. This potential shift could be attributed to higher $\mathrm{CO}_{\text {ads }}$ coverages resulting from enhanced $\mathrm{C}-\mathrm{C}$ bond cleavage of ethylene glycol versus that of ethanol on Pd surfaces. ${ }^{36}$ In analogy to the explanations for EOR, the lowest onset potential and peak potential for EGOR on $\mathrm{Pd}(110)$ may be attributable to the lowest potential for $\mathrm{OH}_{\text {ads }}$ formation, whilst the highest oxidation peak current on $\mathrm{Pd}$ cubes may arise from both the most favoured dehydrogenation of ethylene glycol and the facile subsequent oxidation of the majority of $\mathrm{HO}-\mathrm{CH}_{2} \mathrm{C}^{*}=\mathrm{O}$ and $\mathrm{CO}_{\text {ads }}$ intermediates on $\{100\}$ nanofacets. After anodic polarization at $0.82 \mathrm{~V}$ for 3600s (Figure 4d), the current densities of EGOR on Pd cubes, RDs and Octs remained 64\%, $64 \%, 61 \%$ of their initial values, respectively. The relatively higher durability seen in Figure $4 \mathrm{~d}$ than that in Figure $4 \mathrm{~b}$ is likely due to the fact that $\mathrm{CO}_{\mathrm{ads}}$ oxidative removal at $0.82 \mathrm{~V}$ was more facile than that at $0.67 \mathrm{~V}$ due to weaker $\mathrm{CO}_{\text {ads }}$ bonding to the surface at the higher potential. ${ }^{33}$ In addition, a closer look at Figure $4 \mathrm{~d}$ reveals that the oxidation current decayed at a larger slope for EGOR on Pd RDs than on Pd cubes after $100 \mathrm{~s}$, despite a higher current due to the lowest onset potential on Pd RDs as seen in Figure 4c. This observation suggests that $\mathrm{Pd}$ cubes are more suitable for longer operation in EGOR (see ESI for the discussion on this).

In conclusion, both ethanol oxidation reaction (EOR) and ethylene glycol oxidation reaction (EGOR) on nano-sized $\mathrm{Pd}$ cubes, octahedrons (Octs) and rhombic dodecahedrons (RDs) in alkaline media have been demonstrated to be nanofacet sensitive. The electrocatalytic activities in terms of oxidation peak current densities follow the sequence of cubes $>$ Octs $>$ RDs for EOR and that of cubes $>$ RDs > Octs for EGOR. The nanofacet dependent affinity and reactivity of $\mathrm{OH}_{\text {ads }}$ and $\mathrm{CO}_{\text {ads }}$ significantly affect the EOR and EGOR on differently shaped Pd nanocrystals. The highest electrocatalytic activities of EOR and EGOR on Pd cubes may be ascribed to the most favoured dehydrogenation and subsequent oxidation of majority of (hydroxyl)acetyl and $\mathrm{CO}_{a d s}$ intermediates on $\{100\}$ nanofacets, whilst the lowest onset and peak potentials of EOR and EGOR on Pd RDs were attributed to the formation of $\mathrm{OH}_{\text {ads }}$ at the lowest potential on $\mathrm{Pd}\{110\}$ nanofacets. The current finding suggests clearly that $\mathrm{Pd}$ nanocubes are the choice of catalysts for direct C2 alcohol alkaline fuel cells as well as C2 alcohol electro-reforming cells for hydrogen production.

This work is supported by the NSFC (No. 21473039 and 21733004), the 973 Program of MOST (No. 2015CB932303) and the UK EPSRC (EP/I013229/1).

\section{Conflicts of interest}

There are no conflicts to declare.

\section{Notes and references}

View Article Online DO।. $10.1039 / C 7 C C 08793 D$

1 C. Bianchini and P. K. Shen, Chem Rev, 2009, 109, 4183-4206.

2 H. Yue, Y. Zhao, X. Ma and J. Gong, Chem Soc Rev, 2012, 41, 4218-4244.

3 Y. X. Chen, A. Lavacchi, H. A. Miller, M. Bevilacqua, J. Filippi, M. Innocenti, A. Marchionni, W. Oberhauser, L. Wang and F. Vizza, Nat Commun, 2014 5, 4036-4042.

4 Y. Wang, S. Z. Zou and W. B. Cai, Catalysts, 2015, 5, 1507-1534.

5 L. L. Zhang, Q. W. Chang, H. M. Chen and M. H. Shao, Nano Energy, 2016, 29, 198-219.

6 H. Wang, B. Jiang, T. T. Zhao, K. Jiang, Y. Y. Yang, J. W. Zhang, Z. X. Xie and W. B. Cai, ACS Catal, 2017, 7, 2033-2041.

7 W. J. Huang, X. Y. Ma, H. Wang, R. F. Feng, J. G. Zhou, P. N. Duchesne, P. Zhang, F. J. Chen, N. Han, F. P. Zhao, J. H. Zhou, W. B. Cai and Y. G. Li, Adv Mater, 2017, 29. 1703057.

8 C. Buso-Rogero, S. Brimaud, J. Solla-Gullon, F. J. Vidal-Iglesias, E. Herrero R. J. Behm and J. M. Feliu, J Electroanal Chem, 2016, 763, 116-124.

9 C. Buso-Rogero, E. Herrero and J. M. Feliu, ChemPhysChem, 2014, 15, 2019 2028.

10 N. Tian, Z. Y. Zhou, N. F. Yu, L. Y. Wang and S. G. Sun, J Am Chem Soc, 2010 132, 7580-7581.

11 J. W. Zhang, L. Zhang, S. F. Xie, Q. Kuang, X. G. Han, Z. X. Xie and L. S. Zheng Chem-Eur J, 2011, 17, 9915-9919.

12 T. T. Zhao, H. Wang, X. Han, K. Jiang, H. X. Lin, Z. X. Xie and W. B. Cai, J Mater Chem A, 2016, 4, 15845-15850.

13 M. Baldauf and D. M. Kolb, J Phys Chem, 1996, 100, 11375-11381.

14 S. Kondo, M. Nakamura, N. Maki and N. Hoshi, J Phys Chem C, 2009, 113, 12625-12628.

15 M. H. Shao, J. Odell, M. Humbert, T. Y. Yu and Y. N. Xia, J Phys Chem C, 2013, 117, 4172-4180

16 N. Tian, Z. Y. Zhou and S. G. Sun, J Phys Chem C, 2008, 112, 19801-19817.

17 Y. C. Yan, J. S. S. Du, K. D. Gilroy, D. R. Yang, Y. N. Xia and H. Zhang, Adv Mater, 2017, 29.

18 W. X. Niu, L. Zhang and G. B. Xu, ACS Nano, 2010, 4, 1987-1996

19 H. X. Zhang, H. Wang, Y. S. Re and W. B. Cai, Chem Commun, 2012, 48, 8362-8364.

20 M. S. Jin, H. Zhang, Z. X. Xie and Y. N. Xia, Energ Environ Sci, 2012, 5, 6352 6357.

21 M. Hara, U. Linke and T. Wandlowski, Electrochim Acta, 2007, 52, 57335748.

22 N. Hoshi, M. Nakamura, N. Maki, S. Yamaguchi and A. Kitajima, Electroanal Chem, 2008, 624, 134-138.

23 Z. X. Liang, T. S. Zhao, J. B. Xu and L. D. Zhu, Electrochim Acta, 2009, 54, 2203-2208.

24 Y. Katayama, T. Okanishi, H. Muroyama, T. Matsui and K. Eguchi, ACS Catal, 2016, 6, 2026-2034.

25 H. Kondoh, R. Toyoshima, Y. Monya, M. Yoshida, K. Mase, K. Amemiya and B. S. Mun, Catal Today, 2016, 260, 14-20.

26 J. S. Ye, S. Y. Hsu and C. L. Lee, Electrochim Acta, 2016, 211, 1024-1032.

27 Y. Y. Yang, J. Ren, Q. X. Li, Z. Y. Zhou, S. G. Sun and W. B. Cai, ACS Catal, 2014, 4, 798-803.

28 R. Cortese, R. Schimmenti, F. Ferrante, A. Prestianni, D. Decarolis and D. Duca, J Phys Chem C, 2017, 121, 13606-13616.

29 E. A. Monyoncho, S. N. Steinmann, C. Michel, E. A. Baranova, T. K. Woo and P. Sautet, ACS Catal, 2016, 6, 4894-4906.

30 F. Maillard, E. R. Savinova and U. Stimming, J Electroanal Chem, 2007, 599 221-232.

31 N. Hoshi, O. Koga, Y. Hori and T. Ogawa, J Electroanal Chem, 2006, 587 79-85.

32 T. Sheng, W. F. Lin, C. Hardacre and P. Hu, J Phys Chem C, 2014, 118, 5762 5772.

33 B. Y. Liu, J. M. Jin, C. Hardacre, P. Hu and W. F. Lin, J Electroanal Chem, 2013, 688, 216-223.

34 J. M. Jin, T. Sheng, X. Lin, R. Kavanagh, P. Hamer, P. J. Hu, C. Hardacre, A Martinez-Bonastre, J. Sharman, D. Thompsett and W. F. Lin, Phys Chem Chem Phys, 2014, 16, 9432-9440.

35 E. D. Wang, J. B. Xu and T. S. Zhao, J Phys Chem C, 2010, 114, 10489-10497

36 J. L. Lin, J. Ren, N. Tian, Z. Y. Zhou and S. G. Sun, J Electroanal Chem, 2013, $688,165-171$ 


\section{Graphical abstract}

Ethanol and ethylene glycol electrocatalytic oxidation on Pd cubic, octahedral and rhombic dodecahedral nanocrystals in alkaline media was systematically investigated.

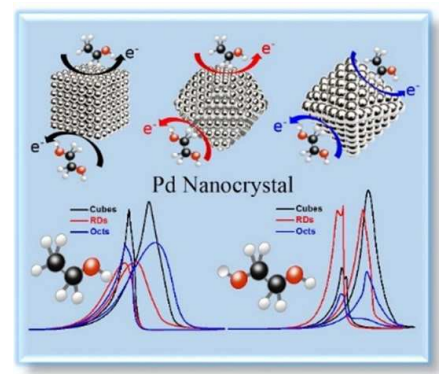

